\title{
Analisis Kesulitan Belajar Membaca Dan Menulis Permulaan PAUD Di Kelompok Bermain Fun Islamic School
}

\author{
Muhammad Azis ${ }^{1}$, Nadia Safirawati Adila ${ }^{2}$ \\ Universitas Islam Negeri Sunan Kalijaga Yogyakarta, Indonesia \\ muhammadazis292@gmail.com
}

\begin{abstract}
Child learning difficulties are children who are disrupted in one o more basic psychological processes that include understanding and using spoken or written language. This study aims to describe the learning difficulties experienced by children aged 5-6 years in group playing FUN ISLAMIC SCHOOL. The method used is a qualitative research method with a case study approach. The data source consisted of 2 teachers in the group of children aged 5-6 years, and 4 children who had problems due to learning difficulties were the case subjects in this study. After data is collected, data is presented for inclusion. Reading difficulties in children aged 5-6 years are different, in the pocess of writing in class children have poor writing in learning activities in class. Based on the results of the study there are a number of suggestions that can be considered by related parties in an effort to overcome the learning difficulties of children.
\end{abstract}

Keywords: difficulty learning, reading, and writing in the beginning.

\begin{abstract}
Abstrak
Kesulitan Belajar anak adalah anak yang terganggu dalam satu atau lebih proses psikologis dasar yang mencakup pemahaman dan penggunaan bahasa tutur atau tulisan. Penelitian ini bertujuan untuk mendeskripsikan kesulitan belajar yang dialami oleh anak usia 5-6 tahun di kelompok bermain Fun Islamic School. Metode yang digunakan adalah metode penelitian kualitatif dengan pendekatan studi kasus. Sumber data terdiri dari 2 guru dalam kelompok anak usia 5-6 tahun, dan 4 anak yang bermasalah karena kesulitan belajar yang menjadi subjek kasus dalam penelitia ini. Setelah data dikumpulkan, data disajikan untuk inklusi. Kesulitan membaca pada anak usia 5-6 tahun yang berbeda, pada proses menulis di kelas anak mengalami kesulitan belajar, anak memiliki tulisan yang buruk dalam kegiatan pembelajaran di kelas. Berdasarkan hasil penelitian ada beberapa saran yang dapat dipertimbangkan oleh pihak-pihak terkait dalam upaya mengatasi kesulitan belajar anak.
\end{abstract}

Kata Kunci: Kesulitan Belajar, Membaca, dan Menulis Permulaan.

\section{PENDAHULUAN}

Anak Usia Dini adalah anak yang berusia 0-8 tahun dengan memiliki kemampuan perkembangan yang sangat pesat atau the golden age (masa keemasan) yang artinya seorang anak mengalami perkembangan yang sangat pesat dalam segala bidang aspek-aspek perkembangan. Baik berupa Aspek perkembangan kognitif, bahasa, sosialemosional, fisik-motorik, moral, dan seni. Oleh karena itu kita sebagai pendidik maupun orang tua tentunya sangat menginginkan agar kita kelak tumbuh menjadi anak yang cerdas. Guru ataupun orangtua akan sangat bangga ketika bisa melihat anak-anak mereka yang masih berusia dini sudah bisa membaca, menulis dan bahkan berhitung dengan baik. Maka dari itu usia dini adalah usia yang sangat tepat untuk membentuk kepribadian yang baik bagi anak. 
Pendidikan ialah sebuah proses perubahan tingkah laku dan sikap seseorang atau sekelompok orang dalam berusaha mendewasakan manusia melalui upaya pelatihan dan pengajaran, cara atau proses maupun bentuk perbuatan mendidik. Maka dari itu didiklah anak sebaik mungkin agar kelak ia bisa menjadi anak yang berbakti kepada kedua orang tuanya. Kesulitan belajar adalah suatu gangguan psikologis yang mencakup dasar penggunaan dan pemahaman ujaran bahasa tulisan. Mengatasi anak yang berkesulitan belajar tidak didasari seberapa banyak ilmu yang kita miliki tetapi seberapa besar kesabaran yang kita punya untuk menghadapi anak tersebut.

Budiyanto mengemukakan (2011:3) Kesulitan belajar adalah suatu gangguan dalam suatu proses psikologi dasar yang mencakup pemahaman dan penggunaan bahasa ujaran atau tulisan". Faktor yang menyebabkan anak berkesulitan dalam belajar yaitu: kerusakan pada otak, emosi yang tidak terkontrol dan peristiwa yang dialami semasa hidupnya. Kerusakan pada otak terjadinya karena ada kerusakan pada syaraf anak seperti dalam kasus encephalitis, maningitis, dan tostik. Kondisi ini dapat memunculkan sebuah masalah fungsi otak yang dibutuhkan untuk proses belajar pada anak dan remaja. Dengan kondisi ini anakanak yang sedang mengalami disfungsi minimal otak/minimal brain dysfunction pada saat lahir akan menjadi gangguan yang sangat besar pada diri anak yang mengalami proses belajar.

Faktor gangguan emosional yang menyebabkan kesulitan belajar dapat dikarenakan adanya ketakutan emosional yang berkepanjangan yang menyebabkan masalah hubungan fungsional sistem urat syaraf. Keadaan perilaku-perilaku yang terjadi seringkali seperti perilaku pada kasus kerusakan otak. Akan tetapi tidak semua trauma emosional menimbulkan masalah saat belajar. Pendidikan yang paling tepat pada anak yang kesulitan dalam belajar dapat dilakukan dengan pendidikan ortopedagogik. Pendidikan ini adalah ilmu pendidikan dari cabang pedagogik yang mempelajari ilmu pendidikan yang erat kaitan dengan anak yang berkesulitan belajar, mampu bekerjasama dengan anak-anak yang lainnya.

Menurut Koswara Deded (2013:19) mengemukakan bahwa kemampuan membaca ialah sebuah pondasi dalam mengatasi sejumlah bidang studi atau pengetahuan yang harus dipelajari anak di sekolah. Kesulitan membaca bagi anak kelas awal akan berdampak sulit bagi kelas yang selanjutnya. Terbatasnya anak yang memiliki kesulitan belajar membaca, guru harus lebih berusaha semaksimal mungkin agar potensi atau kemampuan yang dimiliki oleh murid dapat lebih optimal. Dari hasil wawancara dengan guru, tindakan yang sudah dilakukan dalam mengatasi masalah ini yaitu dengan memberi dukungan dan binaan untuk anak yang berkesulitan dalam belajar membaca.

Guru harus membimbing siswa saat proses belajar sedang berlangsung dengan cara menggulangi kembali materi yang sudah dipelajari sebelumnya tujuannya yaitu agar tidak terlambat dalam pembelajaran yang sudah dipelajari sebelumnya, guru harus selalu memberitahu kembali pelajaran yang sebelumnya. Supaya anak bisa mengingat kembali pelajaran yang disampaikan oleh gurunya minggu yang lalu. Berdasarkan hasil observasi awal yang dilakukan penulis di kelompok bermain Fun Islamic School terdapat ada 4 murid sedang berkesulitan untuk membaca belum terlalu bisa untuk mengetahui hurufhuruf, anak juga masih berkesulitan untuk menulis huruf dengan baik-benar. Menulis dan membaca permulaan ialah sangat perlu untuk kegiatan keseharian anak namun kegiatan 
membaca permulaan dan menulis adalah sesuatu yang sulit untuk dilakukan oleh 4 anak pada kelompok bermain Fun Islamic School karena mereka belum paham bentuk angka dan huruf bagi anak yang berusia lima sampai enam tahun. ketika proses pembelajaran di dalam kelas terdapat 4 orang anak belum bisa menirukan tulisan huruf - huruf abjad sederhana dan huruf - huruf dasar melalui binaan pendidik yang tepat. Anak juga belum bisa membedakan antara huruf $\mathrm{M}$ dan huruf $\mathrm{W}$.

Peneliti melihat bahwa ada beberapa anak yang sudah bisa dalam penyebutan huruf-huruf seperti $b$ dan d namun hanya 4 anak yang belum bisa dalam penyebutan huruf, untuk kedepannya guru atau orang tua harus banyak memiliki ide agar supaya anak bisa menyebut huruf-huruf yang ditunjukkan oleh guru dan orangtua nya, hal ini tidak lain dan tidak bukan dikarenakan masih banyaknya kelalaian dari guru dalam mendidik atau mengajari tata cara penyebutan huruf-huruf dan bisa membedakan huruf, maka dari itu guru dan orangtua harus selalu melihat situasi dari anak setiap harinya, ada perubahan atau tidaknya kedepan.

Sebagai guru harus mengetahui betapa pentingnya seorang guru dalam menyikapi sebuah masalah yang dialami oleh siswa khususnya siswa yang sekolah di kelompok bermain Fun Islamic School. Maka dari itu penulis perlu melakukan penelitian yang lebih mendalam tentang kesulitan belajar pada anak usia dini. Terkhusus pada kelompok bermain Fun Islamic School. Dengan situasi yang terjadi di lapangan seperti ini maka dari itu penulis sangat tertarik untuk meneliti tentang "kesulitan belajar anak usia 5-6 tahun di kelompok bermain Fun Islamic School.

Maka dari itu ada beberapa tahapan perkembangan membaca menurut Cochrane (Brewer, 1995: 218), yaitu:

1. Tahap Magic (Magical Stage), pada tahapan ini anak belajar tentang kegunaan buku, dan menganggap buku itu adalah suatu hal yang dibutuhkan dalam kegiatannya sehari-hari.

2. Tahap Konsep Diri (Self Concept Stage), tahapan ini menunjukkan bahwa anak menganggap bahwa dirinya adalah seorang pembaca, mulai terlihat seperti sedang melakukan kegiatan "pura-pura membaca",

3. Tahap Pembaca Antara atau Tahap Membaca Gambar (Bridging Reading Stage), dalam tahapan ini menunjukkan bahwa anak memiliki ketertarikan terhadap benda ataupun bahan cetak (print) yang mempunyai beberapa gambar.

4. Tahap Lepas Landas atau Tahap Pengenalan Bacaan (Take-off Reader Stage), dalam tahapan ini menunjukkan bahwa anak mulai menggunakan tiga sistem tanda atau ciri khas dalam pengenalan bacaan yang biasa disebut dengan grafofonik, semantik, dan sintaksis. Anak akan mulai membaca semua hal yang dilihatnya dan mengenal huruf secara konteks

5. Tahap Independen atau Tahap Membaca Lancar (Independent Reader Stage), pada tahapan ini menunjukkan bahwa anak sudah membaca semua buku secara mandiri, dan memaknai isinya dari pengalaman sebelumnya. Anak juga sudah bisa memperkirakan sebuah materi bacaan yang akan dibacanya.

Pemahanman konsep suatu kata pada anak akan ditunjukkan saat ia mencocokan setiap perkataan dengan yang dituliskannya. Keterampilan dalam mempelajari tentang huruf dan kata harus dengan bantuan Guru dan Orang tua. Keterampilan yang dibutuhkan 
yaitu mengenal dan mengetahui nama-nama huruf, mengenalkan huruf dapat dilakukan dengan cara mengenalkan huruf yang paling dekat dengan anak, misalnya dapat dicontohkan dengan nama-nama benda kesayangannya. Setelah mengetahui nama-nama hurufnya maka sekarang dapat melanjutkan dengan tahap menghubungkan beberapa huruf dengan permainan bunyi yang disebutkan untuk membentuk sebuah kata, dan mencocokkan kata-kata yang terucap atau kata lisan dengan kata tulisan satu-persatu. Kerampilan yang disebutan di atas mulai dari mengetahui nama-nama huruf, akan membuat anak lebih mudah untuk mengetahui dan mengenal bunyi dari huruf yang mewaili kata benda yang ada disekitarnya.. Saat anak akan belajar mengetahui dan memahami suatu bentuk atau simbol yang mempunyai nama huruf tersendiri, anak akan semakin lebih mudah dalam mengenal dan memahami bentuk, dan bunyi dari suatu huruf tersebut. Anak juga akan lebih menunjukkan pemahamannya terhadap bentuk atau symbol alphabet pada urutan yang seharusnya.

\section{METODE PENELITIAN}

Penelitian ini metode yang ingin penulis lakukan ialah dengan menggunakan salah satu prosedur yang dapat menyelesaikan sebuah permasalahan yang dicaritau dengan membayangkan keadaan objek dan subjek dalam penelitian ini dapat berupa orang, masyarakat lembaga, dan yang lainnya yang ada pada saat sekarang berdasarkan faktafakta yang ada atau apa adanya, karena melalui prosedur ini, penulis dapat melihat secara keseluruhan tentang cara membayangkan seluruh keadaan yang mungkin akan terjadi dalam kenyataan dilapangan sehingga pembaca akan dapat mempunyai perencanaan atau gambaran lebih jelas tentang penelitian yang akan dilaksanakan.

Prosedur akan peneliti lakukan ini, peneliti bermaksud ingin melihat seluruh murid yang berkesulitan dalam belajar khususnya anak yang berusia 5-6 tahun pada kelompok bermain Fun Islamic School. Dalam penelitian ini juga penulis ingin melihat cara-cara guru dalam mengatasi anak yang berkesulitan belajar khususnya pada anak yang berusia 56 tahun pada kelompok bermain Fun Islamic School.

Adapun kasus yang bermasud dalam penelitian ini yaitu sebab ingin memahami lebih lanjut tentang cara pendidik dalam penanggulangi anak yang berkesulitan belajar pada anak usia 5-6 tahun pada kelompok bermain Fun Islamic School. Supaya penelitian ini bisa terlaksanakan dan bisa diselesaikan maka penulis harus menyususun langkah-langkah apa saja yang harus diteliti nantinya. Dan hal yang menyebabkan anak berkusulitan dalam belajar yaitu ada beberapa faktor. Diantaranya adalah:

1. Faktor yang menyebabkan anak berkesulitan dalam belajar yaitu: kerusakan pada otak, emosionalnya terganggu, dan peristiwa yang dialaminya. Kerusakan pada otak terjadi karena ada kerusakan pada syaraf anak seperti dalam kasus encephalitis, maningitis, serta tostik. Keadaan hal seperti ini dapat menyebabkan sebuah masalah kerja otak yang dibutuhkan dalam kegiatan belajar anak dan remaja. Dengan kejadian ini anak - anak yang sedang mengalami disfungsi minimal otak/minimal brain dysfunction saat kelahiran akan menyebabkan 
masalah yang sangat berdampak besar pada proses perkembangan anak dan berdampak besar juga dalam kegiatan belajarnya.

2. Faktor gangguan emosi yang membuat keadaan kesulitan dalam belajar terjadi karena adanya trauma atau ketakutan emosi atau psikologis yang berkelanjutan sehingga dapat menyebabkan gangguan pada hubungan fungsional sistem urat syaraf. Keadaan seperti ini seringkali terjadi pada perilaku pada kasus kerusakan otak. Akan tetapi tidak semua trauma atau ketakutan psikologis emosi dapat mengakibatkan terjadinya gangguan saat belajar.

3. Faktor pengalaman dapat menyebabkan kesulitan dalam belajar yang meliputi faktor-faktor seperti kesenjangan perkembangan atau miskinnya pengalaman dalam lingkungan. Keadaan seperti inilah yang dapat dialami oleh anak terbatas dalam memperoleh stimulus lingkungan yang seharusnya, atau tidak akan pernah bisa mendapatkan kesempatan menangani mainan dan peralatan tertentu, kesempatan seperti itu akan memudahkan anak untuk mengembangkan ataupun meningkatan keterampilan dan kemampuannya memanipulasi dalam menggunakan alat tulis seperti pensil dan mengakibatkan anak tidak terlalu banyak dalam mempunyai pembendaharaan bahasa atau kata-kata yang dibutuhkan untuk berfikir logis/masuk akal dan nalar. Ketidakmilikan atau miskinnya pengalaman sangat berkaitan erat dengan kondisi sosial ekonomi orangtua sehingga sering kali berkaitan erat dengan masalah kekurangan gizi yang pada akhirnya dapat menyebabkan terganggunya optimalisasi perkembangan dan fungsi otak.

Pemahaman faktor terjadinya keadaan ini sangat penting, karena sangat besar hubungannya dengan pendidikan yang sangat membantu saat akan memahami alasanalasan yang ada dibalik masalah ataupun persoalaan saat terjadinya proses belajar, alih-alih berfokus pada sebabnya. Asumsinya adalah bahwa perilaku bermasalah dalam prose belajar itu dapat diubah dan dibentuk jika sekolah mengembangkan struktur pengalaman atau memfasilitasi pemberian pengalaman dalam proses pembelajaran langsung yang dapat memenuhi kebutuhan khusus itu.

Adapun yang menjadi lokasi dalam penelitian ini adalah pada kelompok bermain Fun Islamic School. Subjek dalam penelitian ini adalah Guru kelompok bermain Fun Islamic School terdiri dari dua orang guru, dan murid kelas B berjumlah 4 murid yang sedang berkesulitan pada kelompok bermain Fun Islamic School.

Adapun cara peneliti mengumpulkan data dalam penelitian ini adalah:

a. Peneliti terlebih dahulu melakukan Observasi

b. Peneliti melakukan wawancara kepada guru yang disekolah

c. Penelti melakukan tahap dokumentasi karena tanpa danya dokumentasi datanya kurang valid atau kurang lengkap

Tujuannya adalah supaya informasi yang diperoleh dalam tahap-tahap di atas bisa dipergunakan untuk pembuatan laporan yang telah ada. Adapun cara penganalisa datanya adalah suatu cara yang paling penting untuk proses penelitian. Melalui tahap penganalisis ini, peneliti akan membagi menjadi data yang penting dan data yang tidak penting dalam penelitian. Tahap Selanjutnya peneliti akan mengelompokan data yang serupa atau yang sama agar dapat lebih mudah saat membuat sebuah kesimpulan. Ketika membuat 
kesimpulan, peneliti atau penulis harus lebih hati-hati karena jika penelitian ini tidak sesuai dengan realita yng terjadi dilapangan maka penelitian ini belum dinyatakan berhasil dalam melakukan sebuah penelitian maka dari itu supaya hasil penelitian ini sesuai dengan apa yang dirapkan peneliti harus berhati hati dalam pengecekan data.

Dalam proses analisis data, peneliti harus melakukan beberapa proses, yaitu: analis data dengan menggunakan proses penelitian yang sebenarnya sesuai dengan prosedur yang telah di tetapkan sebelumya, dan hal ini dilakukan supaya peneliti memperoleh sebuah bayangan atau gambaran penelitian sehingga peneliti bisa mengetahui beberapa ciri-ciri yang telah diteliti. Analisisnya dapat di rancang seperti: Perkumpulan data, perkumpulan data adalah sesuatu yang paling penting dalam penganalis data, karena adanya perkumpulan data peneliti dapat membedakan data-data yang layak untuk dipakai yang sesuai, maka peneliti lebih mudah untuk mendapatkan data yang telah ditetapkan sebelumnya. Dalam penelitian ini data yang diterapkan sangat erat kaitannya dengan pendidik yang berada pada kelompok bermain Fun Islamic School. Instrumen utama yang dipakai untuk penelitian kualitatif ini adalah peneliti sendiri (human instrumen), peneliti berusaha memakai setiap data yang diperoleh di lapangan, namun tidak menutup kemungkinan peneliti menggunakan instrumen lain, seperti: panduan observasi, wawancara, dan dokumentasi. Observasi, peneliti mengamati secara langsung proses kegiatan pembelajaran dan aktivitas-aktivitas lain yang sedang berlangsung pada kelompok bermain Fun Islamic School. Wawancara, peneliti menjumpai beberapa narasumber yang dianggap dapat memberikan informasi tentang analisis kesulitan membaca dan menulis permulaan pada kelompok bermain Fun Islamic School siswa yang berlangsung di lokasi penelitian. Dokumentasi, peneliti mengambil beberapa gambar yang dapat melengkapi dengan data-data yang diamati baik itu secara lansung maupun tidak langsung

Dari data yang diperoleh akan dianalisis dengan interaksionis, analisis ini terbentuk dari tiga jalur kegiatan bersamaan yaitu antara pengumpulan data, reduksi data dan pentahapan secara urutan, penyajian data, secara verifikasi pertama dan penarikan kesimpulan, ketika pengumpulan data selesai, maka akan dilakukan reduksi data yakni mengarahkan, mengolongkan, pengorganisasian dan membuang yang tidak diperlukan, sehingga data menjadi pilihan. Kedua, data yang sudah melewati tahap reduksi akan disajikan dalam bentuk deskripsi maupun matrik, tahap ketiga adalah membuat kesimpulan pada setiap perumusan.

\section{1). Data reduksi}

Reduksi data ialah sebuah proses berfikir yang sangat memerlukan kecerdasan dan pemikiran yang sangat mendalam. Setiap peneliti akan dipandu oleh tujuan yang akan dicapai.

2). Penyajian Data

Setelah selesai tahap pengrekdusian data maka selanjutnya yaitu tahap penyajian data, sehingga proses penyajian data akan dapat lebih mudah untuk di pahami (Sugiyono, 2014:341). Penyajian sebagai bentuk informasi yang 
dikumpulkan, dengan adanya kemungkinan dalam mengambil kesimpulan dan mengambil suatu tindakan. Adanya penyajian data dapat memudahkan kita untuk bisa mengetahui kemungkinan yang terjadi dan tindakan yang harus dilakukan.

Langkah selanjutnya yaitu verifikasi atau penarikan kesimpulan. Dengan adanya penarikan kesimpulan kita bisa mengetahui bukti yang lebih kuat dan bisa mendukung pada tahap pengumpulan data. Tetapi kesimpulan yang akan dipaparkan pada awal ini hanya bersifat sementara dan bersifat konkrit, saat penulis kembali kelapangan mengumpulkan data dan didukung oleh bukti yang valid, maka kesimpulannya ialah kesimpulan yang dapat dipercaya.

\section{HASIL PENELITIAN DAN PEMBAHASAN}

Menulis permulaan yaitu sebuah gambaran simbol tertulis. Sebagian besar anak banyak memiliki kesulitan dalam menulis. Hal ini disebabkan oleh gurunya karena masih minimnya perhatian seorang guru kepada muridnya sehingga muridnya masih mengalami kesulitan dalam menulis dan kurangnya binaan atau bimbingan dalam penulisan. Maka dari itu guru harus membina muridnya dalam penulisan agar supaya anak bisa dalam menulis, dan anak bisa menulisnya bisa lebih rapi dan teratur dalam penulisannya.

Dalam penulisan huruf masih banyak terdapat anak yang tidak konsisten dalam bentuk/menulis huruf yang ditulisnya terkadang ada banyak tulisan yang tidak bisa dibaca. Anak menulis menggunakan huruf-huruf secara bersamaan sehingga anak tidak bisa menulis hurufnya secara rapi, konsentrasi belajar anak kurang saat proses penulisan huruf, anak keasyikan melihat temannya yang disamping, anak tidak begitu fokus pada tugas yang diberikan gurunya, anak masih suka mengganggu teman yang berada di samping tempat duduknya. Anak lebih suka mencoret-coret hasil tulisanya apabila terjadi kesalahan.

Kemampuan baca-tulis permulaan sebaiknya tidak diarahkan pada kemampuan akademik, melainkan diarahkan pada kegiatan yang memberikan pengalaman langsung seperti bermain yang dilengkapi dengan berbagai media belajar sambil bermain yang memadai. Maka dari itu diperlukan, peran guru sebagai fasilitator untuk lebih kreatif dalam membuat atau menyediakan media belajar sambil bermain yang dapat memfasilitasi anak saat proses belajar. Media bermain yang disediakan adalah media yang digunakan untuk meningkatkan dan menarik minat bermain anak. Kemampuan membaca permulaan pada anak Kelompok B dilihat berdasarkan pengetahuan huruf yang dimiliki oleh anak. Jika anak mampu atau bisa mengenal berbagai huruf konsonan dan vokal dengan baik, lancar, dan tepat maka hal ini akan memudahkan anak dalam proses mengeja. Dan sebaliknya, jika anak belum bisa atau pengetahuan serta pemahamannya teradap huruf vokal dan konsonan masih rendah maka anak akan mengalami kesulitan untuk bisa memasuki tahapan berikutnya seperti mulai mengeja dari suku kata sederhana sampai suku kata yang paling sulit untuk dilakukan oleh anak.

Karakteristik anak berkesulitan belajar dapat dijumpai pada seluruh anak yang diindentifikasikan sebagai anak berkesulitan belajar. Sebagian anak mungkin masih memperlihatkan kesulitan dalam aspek kognitif, dengan masalah-masalah khusus seperti 
menulis, membaca, berhitung, dan bahkan berfikir. Masalah lain yang muncul mungkin dalam aspek sosialnya, seperti berinteraksi dengan orang lain, konsep pengenalan dirinya sendiri, dan perilaku-perilaku yang tidak seharusnya dilakukan. Sementara yang lainnya mungkin masih bermasalah pada aspek bahasa, permasalahan yang muncul bisa berupa kesulitan untuk bisa mengekspresikan diri secara lisan maupun tulisan. Ada kemungkinan lain, dimana penyebab anak yang berkesulitan saat proses belajar bermasalah dalam aspek perkembangan motoriknya. Dari pemikiran tersebut maka pembahasan aspek-aspek perkembangan berikut ini bisa jadi tidak berlaku secara keseluruhan bagi semua anak-anak yang berkesulitan dalam belajar. Yang terdiri dari beberapa aspek yaitu: a) aspek kognitif, permasalahan kesulitan belajar lebih dominan kepada perkembangan aspek berfikir atau akademik. Masalah kemampuan berbicara, membaca, menulis, mendengar, berfikir, dan matematik semua merupakan penekanan terhadap anak dalam perkembangan pemikiran atau akademik. Penekanan seperti ini merefleksikan keyakinan bahwa masalah anak berkesulitan dalam belajar sangat banyak berhubungan dengan wilayah akademik dan bukan dikarenakan oleh tingkat kecerdasan yang kurang ataupun rendah. Permasalahan yang terjadi dalam kesulitan membaca yang paling sering dijumpai di sekolah ialah contoh klasik dari kekurangan keberfungsinya aspek kognitif anak yang sulit dalam melakukan proses belajar. Tidak memungkiri bahwa anak yang mengalami kesulitan membaca akan memperlihatkan keterampilan berhitung atau matematika yang terlalu tinggi. Permasalahan seperti ini menunjukkan bahwasannya anak megalami berkesulitan dalam belajar memiliki keterampilan berfikiran yang normal, hanya saja keterampilan tersebut tidak berjalan sesuai dengan yang seharusnya sehingga menyebabkan terjadi keterbelakangan akademik yaitu kesenjangan antara yang seharusnya dilakukan anak dengan yang semestinya ditargetkan secara nyata. b) aspek perkembangan bahasa, permasalahan yang terjadi dalam perkembangana bahasa anak biasanya akan berhubungan dengan bahasa respetif maupun eksresif. Bahasa reseptif adalah keterampilan dalam menerima dan memahami informasi atau bahasanya yang diterimanya. Bahasa ekspresif ialah keterampilan dalam mengungkapkan diri melalui ucapan ataupun perkataan. keterampilan bahasa ini bisa kita lakukan dengan membuat tes keterampilan berbahasa untuk bisa dipahami dengan mudah, misalnya mengunakan tes yang bahasanya tidak mungkin dibicarakan. c) aspek perkembangan motorik, permasalahan dalam perkembangan ini ialah masalah yang biasanya dikaitkan dengan kesulitan dalam belajar. Permasalahan ini biasanya anak akan kesulitan dalam belajar yang berhubungan dengan koordinasi mata dan tangan yang dibuthkan dalam meningkatkan perkembangana anak dalam menitu rancangan atau bentuk pola.. Kemampuan ini sangat dibutuhkan anak dalam membuat gambar, meniru tulisan, dan dibuthkan dalam kegiatan menggunting. Keterampilan itu sangat diperlukan berkoordinasi dengan baik antara mata dan tangan yang dalam banyak hal koordinasi tersebut tidak dimiliki oleh anak yang kesulitan dalam belajar. d) aspek perkembangan sosial dan emosi, karakteristik yang sering dikatakan sebagai karakter dari perkembangan sosial emosional anak yang kesulitan dalam proses belajar yaitu: tingat emosi yang berlebihan dan ke imflusian. Berlebihan emosio ini sering ditunjukkan dengan berubahnya suasana atau kondisi hati dan ketidakmampuan anak dalam menekan emosi marahnya. ke imflusian merujuk pada ketidakmampuan kendali emosi terhadap rangsangan yang diterima. 
Berdasarkan paparan yang telah dijelaskan maka karateristik anak yang kesulitan dalam belajar tidak terjadi pada keseluruhan anak. Sebab setiap kesulitan belajar yang mempunyai tanda dan karakteristiknya tersendiri. Hal seperti ini secara ringkas membahas beberapa jenis yang membuat kesulitan belajar spesifik beserta tanda dan karakteristiknya. Tanda dan karakteristik permasalahan yang ditemukan bisa digunakan untuk mengidentifikasi anak berkesulitan belajar maupun dalam berupaya merancang layanan pendidikan, layanan psikologis, dan remediasinya. Sebab-sebab terjadinya kesulitan belajar pada anak 1) tidak berfungsinya minimal otak, tidak fungsinya minimal otak dilakukan untuk menunjukkan suatu keadaan permasalahan pada syaraf minimal anak. Ketidakberfungsiannya ini terjadi pada keadaan gangguan syaraf minimal pada anak. Ini juga bisa termanifestasi dari jenid-jenis kesulitan seperti: fungsi motorik, impulse / dorongan pengendalian perhatian, memori, bahasa, konseptualisasi, maupun persepsi.

Sekalipun keadaannya terlihat pada usia prasekolah, akan tetapi pada anak lain belum tentu terlihat saat anak memasuki sekolah dasar. Anak-anak yang melewati masa dalam ketidakberfungsinya otak minimal mungkin akan memperlihatkan berbagai simptom. Keadaan ini memungkinkan anak akan menghadapi sulitnya dalam melewati kegiatan kelas seperti membaca, mengeja, dan berhitung: kesulitan ini juga dapat mempengaruhi anak dalam pemahaman terhadap konsep nyata ataupun abstrak, ketidak teraturan dalam memahami bidang atau bentuk seperti lebih banyak, lebih sedikit, lebih rendah, lebih tinggi dan bentuk benda yang lainnya. Keadaan ini akan membuat mereka sering memperlihatkan tanda-tanda ketidakmampuan dalam memfokuskan perhatian, ketidakstabilan emosi, frustasi, dan sikap tidak berkeinginan untuk berteman.

Jenis simptom spesifik dari tidak berfungsinya otak minimal adalah: 1. Lemahnya dalam persepsi dan pembentuka konsep, diantaranya yaitu: lemah dalam membedakan ukuran, lemah dalam membedakan kanan-kiri dan bawah atas, lemah tikian kurang, lemah pengenalan waktu, lemah untuk memperkirakan jarak, lemah membandingkan bagian keseluruhan, lemah memahami keutuhan. 2. Permasalahan komunikasi serta berbicara diantaranya yaitu: lemahnya membandingkan stimulus auditif, perkembangan bahasa yang lambat, sering kali kehilangan pendengaran, sering berbicara tak teratur. 3. Terganggu fungsi motorik diantaranya yaitu: sering menunnjukkan kekakuan gerak atau gemetar, hipoaktivitas, hiperaktifivata. 4. Mundurnya prestasi dan penyusuainya akademik diantaranya yaitu: ketidak cakapan membaca, ketidak cakapan berhitung, ketidak kacapan mengeja, ketidak cakapan menulis dan menggambar, lambat dalam menyelesaikan pekerjaan, bingung dalam memahami intruksi. 5. Karakteristik emosional diantaranya yaitu: ekplosif, implusif, lemah kendali emosi dan dorongan, toleransi rendah terhadap frustasi. 6. Terganggunya proses berfikir diantaranya yaitu: berbicara tidak berfikir abstrak, berfikir umumnya konkrit, kesulitan membentuk konsep, sering kali berfikir yang tidak terorganisasi, terbatasnya rentang memori, sering berfikir autistik.

Menurut Cattell manusia membutuhan waktu sedikit lebih memakan waktu yang banyak untuk membaca huruf-huruf yang tidak berkesinambungan daripada membaca huruf yang sudah tersusun dalam sebuah kata. (Sternberg, 2008: 326). Mengatakan bahawa ada tiga tahap pengetahuan anak dalam membaca sebuah kata diantaramya yaitu : (1) 
logographic (usia pra-sekolah); tahapan ini anak mulai membaca kata sebagai satu kesatuan yang kompleks dan pusat perhatian anak akan lebih berminat terhadap gambar yang tersedia didekat tempatnya bermain; (2) alfabetis (usia kindegarten), tahapan ini anak menggunakan huruf untuk mengartikan kata-kata dan anak memusatkan perhatiannya terhadap huruf; dan (3) orthographic (usia sekolah dasar), tahapan ini biasanya anak akan memulai membentuk pola pada kata-kata ataupun huruf. Hal ini harus diteliti pada anak usia pra-sekolah agar lebih memperhatikan media gambar yang disediajan guru untuk anak.

Pada kelompok bermain Fun Islamic School banyak nya anak yang terdapat berkesulitan dalam membaca dan menulis permulaan. Kesulitan membaca bagi anak lebih suka membaca tulisannya secara terbalik balik atau terkukar tukar contontoh guru menyuruh anak untuk membaca huruf $d$ dan anak membacanya huruf $b$, guru terkadang terlalu sering mengulang-ngulang pelajaran. kadang Anak ini membaca dengan benar huruf yang disampaikan guru akan tetapi terkadang anak juga sering lupa. anak juga sering menulis dengan huruf terbalik-balik, contoh yang disampaikan oleh gurunya $\mathrm{b}$ malah yang tulis oleh anak huruf d, konsistensi anak masih kurang dalam penulisan huruf-huruf. anak selalu sulit dalam menyebutkan kembali apa yang telah disampaikan oleh gurunya baik dalam pengulangan kata-kata maupun mengenai tema pelajaran yang akan diujikan gurunya di dalam ruangan.

Anak suka tidak memperhatikan atau mendengar apa yang sedang disampaikan oleh gurunya dan bahkan tidak memperdulikan pembelajaran di kelas yang sedang berlangsung. Anak memiliki tulisan yang buruk dan bahkan tidak bisa dibaca oleh gurunya maupun orang lain yang berada disekelilinginya, pada sat guru melihat anak suka sekali menulis dengan tulisan yang tidak jelas terkadang gurunya telah berusaha mengulangngulanginya sampai berkali- kali setelah itu guru meminta kepada anak untuk menulis nya kembali sesuai yang telah di ajari gurunya tadi. Selama proses pemantauan dari guru anak tidak terlalu suka menggambar dengan kurang baik, hasil gambarannya itu guru masih bisa melihat dan memantau atau yang ditulis oleh anak guru masih mampu lihat selama proses pemantauan. Anak juga sering susah mengikuti perintah atau tugas melalui ucapan yang disampaikan oleh guru kepada anak yang butuh arahan dari guru secara lebih khusus lagi.

Dalam proses observasi murid sering kebingungan dalam membedakan antara kiri dan arah kanan jika pendidik sudah mengulanginya sampai beberapa kali maka murid baru bisa lebih mengetahuinya. selama proses pemantauan murid suka dipertanyakan tentang cerita yang baru saja disampaikan guru dan anak masih suka kesulitan untuk memahami cerita yang baru disampaikan gurunya. anak masih memiliki keadaan telinga serta mata dalam kondisi baik. Guru perlu memberitahu dengan beberapa kali tetapi anak tidak bisa ingat apa yang barusan disampaikan oleh gurunya. Pada tahap selanjutnya. Peneliti melihat bahwa anak masih sulit dalam penggabungan huruf-huruf.

Pada kelompok bermain Fun Islamic School banyak nya anak yang terdapat berkesulitan dalam membaca dan menulis permulaan. Kesulitan membaca bagi anak lebih suka membaca tulisannya secara terbalik balik atau terkukar tukar contontoh guru menyuruh anak untuk membaca huruf $d$ dan anak membacanya huruf $b$, guru terkadang terlalu sering mengulang-ngulang pelajaran. kadang Anak ini juga tepat membaca huruf yang disampaikan gurunya akantetapi terkadang anak juga sering tidak mengingat apa 
yang disampaikan. Anak juga sering menulis dengan huruf terbalik-balik, contoh yang disampaikan oleh gurunya $b$ malah yang tulis oleh anak huruf $d$, konsistensi anak masih kurang dalam penulisan huruf-huruf. anak selalu sulit dalam menyebutkan kembali apa yang telah disampaikan oleh gurunya baik dalam pengulangan kata-kata maupun mengenai tema pelajaran yang akan diujikan gurunya di dalam ruangan. Anak ini sering menulis dalam keadaan lalai dan tidak memperhatikan apa yang sedang ditulisnya sehingga lama kelamaan tulisannya semakin keluar dari garis buku dan sehingga bentuk tulisannya semakin miring dan semakin besar sehingga tulisannya tidak rapi.

Bagian ini peneliti memaparkan tentang kesulitan belajar membaca pada anak yang berusia 5-6 hahun di kelompok bermain Fun Islamic School peneliti akan memaparkan hasil penelitian yang peneliti teliti pada kelompok bermain Fun Islamic School, tentang kesulitan belajar anak usia 5-6 tahun pada kelompok bermain Fun Islamic School. Berdasarkan yang peneliti observasi, wawancara dan dokumentasi ada beberapa anak yang masih mengalami kesulitan dalam belajar, anak belum bisa membaca huruf secara benar, anak mudah lupa dengan huruf yang baru saja diperlihatkan oleh gurunya. anak sering mengalami kesulitan dalam penyebutan kembali apa yang disampaikan oleh gurunya. Menurut analisis peneliti anak masih banyak mengalami kesulitan dalam membaca, oleh karena itu gurunya sangat dituntut untuk setiap harinya selalu mengevaluasi kembali setiap pelajaran yang telah diberikan.

\section{SIMPULAN DAN SARAN}

Secara umum peneliti dapat menyimpulkan bahwa kesulitan belajar anak usia 5-6 tahun pada kelompok bermain Fun Islamic School, masih banyak mengalami kesulitan dalam mebaca dan masih banyak mengalami kesulitan dalam menulis hal ini sebabkan minimnya perhatian dari seorang guru dan orangtua terhadap anaknya, kurangnya perhatian anak terhadap guru, perlunya bimbingan secara lebih khusus lagi bagi seorang anak agar supaya yang ingin dicapai cepat terpenuhi.

Menulis permulaan yaitu sebuah gambaran simbol tertulis. Sebagian besar anak banyak memiliki kesulitan dalam menulis. Hal ini disebabkan dengan minimnya perhatian seorang guru kepada muridnya sehingga muridnya mengalami kesulitan dalam menulis karena kurangnya binaan dalam penulisan. Maka dari itu uru harus membina muridnya dalam penulisan agar supaya anak bisa dalam menulis. Pada kelompok bermain Fun Islamic School banyak nya anak yang terdapat berkesulitan dalam membaca dan menulis permulaan. Kesulitan membaca bagi anak lebih suka membaca tulisannya secara terbalik balik atau terkukar tukar contontoh guru menyuruh anak untuk membaca huruf d dan anak membacanya huruf $b$, guru terkadang terlalu sering mengulang-ngulang pelajaran. kadang Anak ini membaca dengan tepat huruf yang disampaikan gurunya akantetapi terkadang anak ini juga tidak mengingat. anak juga sering menulis dengan huruf terbalik-balik, contoh yang disampaikan oleh gurunya $b$ malah yang tulis oleh anak huruf $d$, konsistensi anak masih kurang dalam penulisan huruf-huruf. anak selalu sulit dalam menyebutkan kembali apa yang telah disampaikan oleh gurunya baik dalam pengulangan kata-kata maupun mengenai tema pelajaran yang akan diujikan gurunya di dalam ruangan. 
Berdasarkan kesimpulan peneliti yang dipaparkan di atas maka dari itu memilki beberapa saran kepada guru dan orangtua untuk kedepan menjadi lebih mudah dalam mengatasi anak yang berkesulitan dalam membaca dan menulis adapun sarannya yaitu:

1) Guru hendaknya lebih akrab dengan anak dan orangtuanya agar bisa membuat pembelajran yang lebih menarik buat anak agar anak lebih tertarik dalam belajar

2) Orangtua harus banyak perhatian terhadap anak agar anak merasa diperhatiin oleh orangtuanya dan gurunya.

3) Buatlah media pembelajaran semenarik mungki bagi anak agar anak tidak mudah bosan dalam mengikuti proses pembelajaran kedepannya.

\section{DAFTAR PUSTAKA}

Budiyanto, Unggul. (2011). Upaya Guru Dalam Mengatasi Kesulitan Belajar. Yogyakarta: Universitas PGRI

Deded. (2013). Pendidikan Anak Berkebutuhan Khusus Berkesulitan Belajar Spesifik. Bandung: Luxima metro media.

Dalyono, M. (2001). Psikologi pendidikan. Jakarta : Rineka Cipta

Desmita. (2006). Psikologi Perkembangan. Bandung : Remaja Rosdakarya

Djamarah, S.B. (2002). Psikologi Belajar. Jakarta : Rineka Cipta

E.Kosasih. (2012). Cara Bijak Memahami Anak Berkebutuhan Khusus .Bandung : Yrama Widya.Bandung

Hurlock, E.B. (1980). Psikologi Perkembangan. Jakarta : Erlangga

Khadijah. 2012. konsep Dasar Pendidikan Prasekolah. Medan: PerdanaMulya Sarana.

Laely, Khusnul. 2013. Peningkatan Kemampuan Membaca Permulaan Melalui Penerapan Media Kartu Gambar. 7(2).

Lestari, N. 2013. Peningkatan Kemampuan Baca-Tulis Permulaan Melalui Penggunaan Wayang Abjad Kontekstual. 7(2). 202.

Pertiwi, A.D. (2016). Study Deskriptif Proses Membaca Permulaan Anak Usia Dini. 5(1). 764.

Santrock, J.W. 2007. Perkembangan Anak 2. Alih bahasa oleh Mila Rahmawati. Jakarta : Erlangga

Soemanto. W. 1998. Psikologi Pendidikan. Jakarta : Rineka Cipta

Sugiyono, 2005. Memahami Penelitian Kualitatif. Jakarta. Alfabeta

Sugiyono. 2014. Metode Penelitian Pendekatan Kuantitatif, Kualitatif dan R\&D. Bandung: Alfabeta

Sutjihati somantri. 2012. Psikologi Anak Luar Biasa. Bandung: Refika Aditama 
Poerwandari, E.K. 1998. Pendekatan Kualitatif dalam Penelitian Psikologi. Jakarta : LPSP3 Fakultas Psikologi UI 